DOI:10.22337/2587-9618-2018-14-3-14-25

\title{
ABOUT METHODS OF SEISMIC ANALYSIS OF UNDERGROUND STRUCTURES
}

\author{
Alexander M. Belostotsky 1, 2, 3, 4,5, Pavel A. Akimov 1, 2, 3, 6, Dmitry S. Dmitriev ${ }^{1}$ \\ ${ }^{1}$ Scientific Research Center "StaDyO”, Moscow, RUSSIA \\ 2 Tomsk State University of Architecture and Building, Tomsk, RUSSIA \\ ${ }^{3}$ Peoples' Friendship University of Russia, Moscow, RUSSIA \\ ${ }^{4}$ Russian University of Transport» (RUT - MIIT), Moscow, RUSSIA \\ ${ }^{5}$ Perm National Research Polytechnic University, Perm, RUSSIA \\ ${ }^{6}$ Russian Academy of Architecture and Construction Sciences, Moscow, RUSSIA
}

\begin{abstract}
As is known, underground facilities are an integral part of the infrastructure of modern society. These objects have some specific characteristics such as complex construction, high cost, long life cycle, etc. Once it is destroyed, the direct and indirect losses are more seriousness than the general structure in the ground. Underground facilities built in areas subject to earthquake activity must withstand both seismic and static loading. Therefore, it is very important to carry on the seismic design of the underground structure in a safe and economical way. The distinctive paper presents a summary of the current state of seismic analysis for underground structures. Classification and brief overview of methods of seismic analysis of underground structures (force-based methods, displacement-based methods, numerical methods of seismic analysis of coupled system "soil - underground structure") are presented, problems of soil-structure interaction are under consideration as well. So-called static finite element method with substructure technique for seismic analysis of underground structures is described.
\end{abstract}

Keywords: seismic analysis, numerical methods, underground structures, finite element method, force-based methods, displacement-based methods, coupled system "soil - underground structure", static finite element method, substructure technique

\section{О МЕТОДАХ СЕЙСМИЧЕСКОГО РАСЧЕТА ПОДЗЕМНЫХ СООРУЖЕНИЙ}

\author{
А.М. Белостоцкий ${ }^{1,2,3,4,5, \text { П.А. Акимов }}{ }^{1,2,3,6}$, Д.С. Дмитриев ${ }^{1}$ \\ ${ }^{1}$ Научно-исследовательский центр СтаДиО, г. Москва, РОССИЯ \\ 2 Томский государственный архитектурно-строительный университет, г. Томск, РОССИЯ \\ 3 Российский университет дружбы народов, г. Москва, РОССИЯ \\ ${ }^{4}$ Российский университет транспорта (МИИТ), г. Москва, РОССИЯ \\ ${ }^{5}$ Пермский национальный исследовательский политехнический университет, г. Пермь, РОССИЯ \\ ${ }^{6}$ Российская академия архитектуры и строительных наук, г. Москва, РОССИЯ
}

\begin{abstract}
Аннотация: Как известно, в настоящее время подземные сооружения являются, по существу, важнейшей составляющей современной инфраструктуры. Подземные объекты характеризуются целым рядом специфических особенностей, в числе которых можно указать, в частности, трудоемкость возведения, высокую стоимость, достаточно продолжительный жизненный цикл. Очевидно, что в случае разрушения подземного сооружения соответствующие прямые и непрямые потери будут более существенны, чем при разрушении надземного здания или сооружения. Подземные объекты, возведенные в сейсмоопасных районах, разумеется, должны воспринимать без разрушения как сейсмические, так и статические нагрузки. Таким образом, задача экономически обоснованного проектирования безопасных сейсмостойких подземных сооружений является исключительно актуальной. В настоящей статье рассматриваются современные методы сейсмического расчета подземных сооружений. В частности, приведены классификация и краткий анализ последних (методы, основанные на задании эквивалентных нагрузок; методы, основанные на задании эквивалентных перемещений; численные методы расчета связанных систем типа «сооружение - основание»), затронуты проблемы моделирования взаимодействия подземного сооружения с
\end{abstract}


окружающим грунтовым массивом, представлено описание так называемого статического метода конечных элементов для расчета подземных сооружений, основанного на технике метода подконструкций.

\begin{abstract}
Ключевые слова: сейсмический расчет, численные методы, подземные сооружения, метод конечных элементов, эквивалентные нагрузки, эквивалентные перемещения, связанная система типа «сооружение - основание», статический метод конечных элементов, метод подконструкций
\end{abstract}

\section{INTRODUCTION}

As is known, underground facilities are an integral part of the infrastructure of modern society $[1,2]$. Underground structures, tunnels, subways, metro stations and parking lots, are crucial components of the build environment and transportation networks. They are more and more frequently constructed especially in densely populated urban areas to facilitate different needs. These objects have some specific characteristics such as complex construction, high cost, long life cycle, etc. Once it is destroyed, the direct and indirect losses are more seriousness than the general structure in the ground [35]. Thus, considering importance of underground structures for life save and economy, their appropriate seismic design is of prior significance [6-17]. However, underground facilities built in areas subject to earthquake activity must withstand both seismic and static loading [18]. Therefore, it is very important to carry on the seismic design of the underground structure in a safe and economical way.

A review of the past performance of hundreds underground openings during earthquakes indicated that underground structures in general are less severely affected than surface structures at the same geographic location. However, some severe damage, including collapse has been reported. We should mention here, in particular, that some underground structures have experienced significant damage in recent large earthquakes, including the 1995 Kobe, Japan earthquake, the 1999 Chi-Chi, Taiwan earthquake and the 1999 Kocaeli, Turkey earthquake (Figure 1). Ground shaking due to wave propagation and permanent ground displacements due to lateral spreading, landslides and fault rupture are affecting underground structures during a strong earthquake [5]. The deformation modes dominating the seismic response are somehow different from aboveground structures (Figure 2).

These recent damages revealed some important weaknesses in the current seismic design practices. For instance, stability of tunnels during seismic motion is affected by peak ground parameters, earthquake duration, type of support, ground conditions and in situ stresses. Moreover, underground structures are quite vulnerable to ground failures associated with large permanent deformations, caused by ground liquefaction, slope instability and fault movements [20]. The distinctive paper presents a summary of the current state of seismic analysis for underground structures. The complexity of the problem and the conscience on the various shortcomings of the available methods lead often to an overdesign of the new structures. The lack of knowledge is attributed, to a certain degree, to the relatively few well documented cases of important damages during strong earthquakes. Several questions regarding their real seismic behavior during shaking remain still nonresponded.

In densely populated urban areas, tunnels and other underground structures are often passing beneath high-rise buildings or they are located close to them. The existence of these structures may create complex interaction effects with the underground structures usually referred as "city effects" [5]. These effects can affect the seismic wave propagation field, altering the seismic input motion with respect to the free field case [6, 14]. In this sense, they may modify considerably the seismic response of the underground structure, while at the same time the existence of the embedded structure, close to the surface and buildings foundations may alter the response of the buildings themselves. 
a)

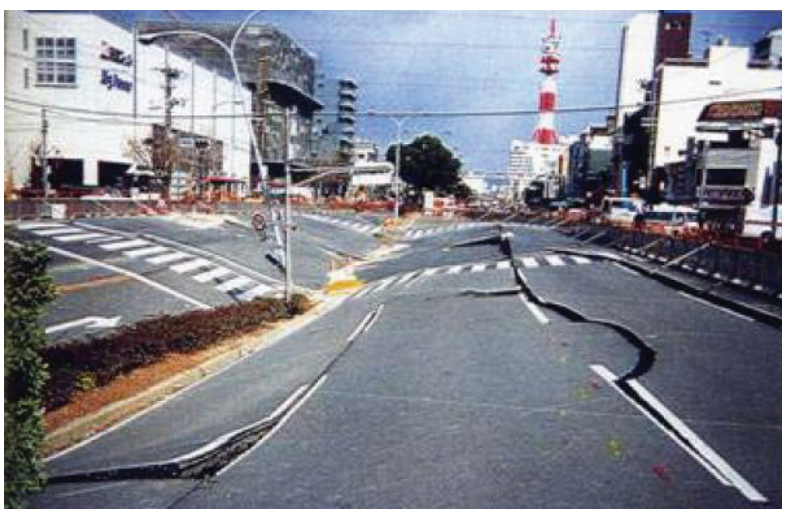

b)

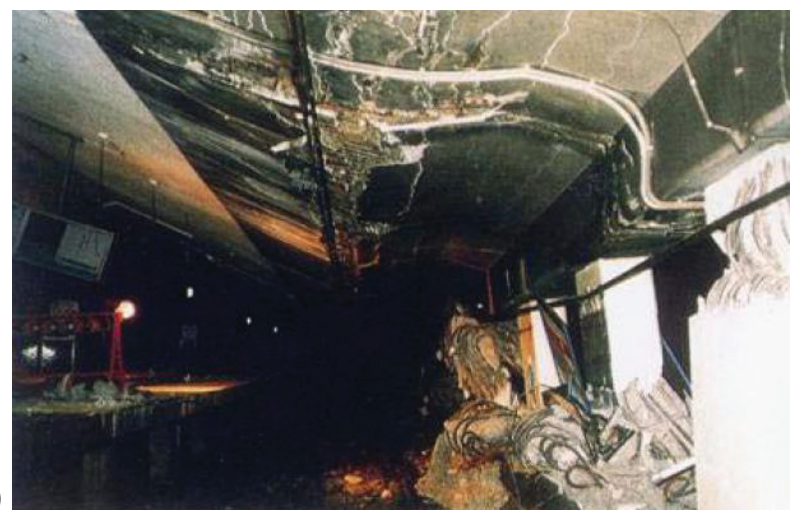

Figure 1. Daikai Station that collapsed during the major Hyogoken-Nambu earthquake (1995).

(a) Settlements of the overlaying roadway caused by the subway collapse.

(b) collapse of the central columns of the station [19].

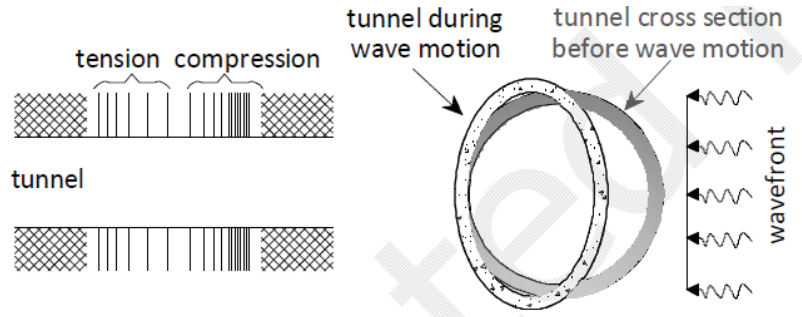

(a) compression-extension

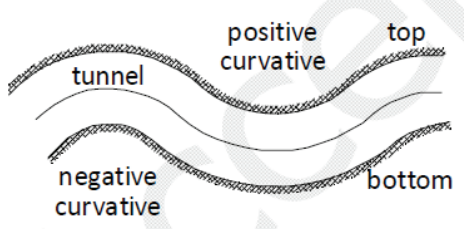

(c) longitudinal bending (b) compression of tunnel section

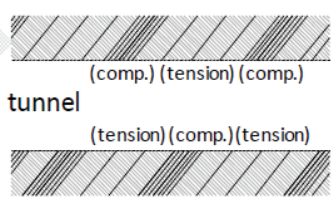

(d) diagonally propagating wave

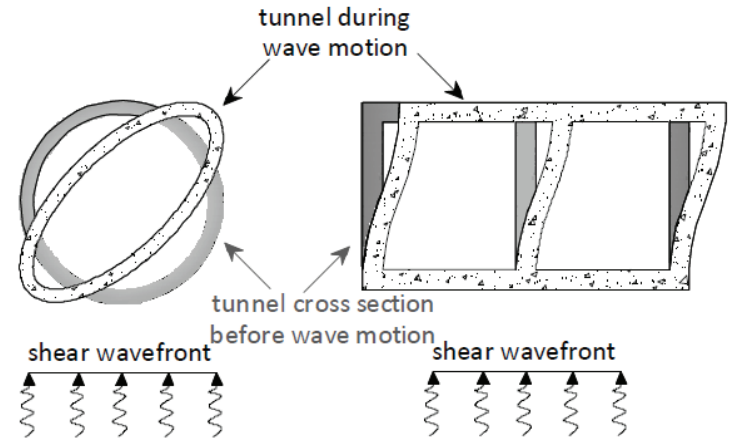

(f) racking of tunnel section

Figure 2. Simplified deformation modes of tunnels due to seismic waves [18].

\section{CLASSIFICATION OF METHODS OF SEISMIC ANALYSIS OF UNDERGROUND STRUCTURES}

As is known, several methods have been proposed in the literature and used in practice for the seismic design of tunnels and large underground structures. From simple analytical elastic solutions, to pseudo-static or equivalent static solutions, and from hybrid methods, which try to take into account the relative stiffness of the ground and the structures and the soilstructure interaction (SSI) effects, to more sophisticated and a priori accurate models using full dynamic numerical analysis of the soilstructure system.
Generally, several methods are available in the literature for the seismic design of tunnels and large underground structures [3,5,8,22,25]. These methods can be classified in three general categories.

\subsection{Force-based methods.}

According to these methods, the seismic load is introduced in terms of equivalent forces acting on the structure in a static way. The structure is commonly simulated as a frame model using beam elements. The main differences between the methods are related to the way that the equivalent forces are estimated and the way the soil-structure interaction is modeled, if accounted. It should be noted that the real 
seismic loading on tunnels and underground structures is applied through the seismic wave propagation and the associated ground distortions imposed on the underground structure. So, displacement-based design is appropriate and consistent with the physics of the problem. Besides, the displacement-based methods are also more appropriate for the efficient seismic design of reinforced concrete (RC) underground structures with ductility higher that unity.

\subsection{Displacement-based methods.}

Contrary to the force-based methods, in the displacement-based methods the seismic load is introduced in terms of seismic displacements, an assumption, which is closer to the problem's physics. Once again, the main differences between the methods are related to the way that the seismic displacements are computed and the way in which the soil-structure interaction is modeled, if accounted. Force-based design, despite several drawbacks, remains always familiar to the engineering community and simpler to apply (in comparison with displacement-based design). Several arguments, in favor of the inconsistency of force-based design, as discussed by $[23,24]$ are also valid in the case of large space underground structures and tunnels.

\subsection{Numerical methods of seismic analysis of coupled system "soil - underground structure".}

Full dynamic time history analysis is considered to be the most sophisticated and accurate method for the seismic analysis of underground structures [22] (finite element or finite difference techniques are always used). However, complex and time consuming computer analysis is required and uncertainty of design seismic input parameters may be several times the uncertainty of the analysis [18]. These analyses involve setting artificial boundaries and soil dynamic constitutive and other issues, and it is difficult widely used in engineering. However, numerical methods can efficiently describe the kinematic and inertial aspects of the soil-structure interaction and the complex geometry of the soil deposit. Moreover, the nonlinear behavior of both the structure and the soils can be efficiently simulated using appropriate constitutive laws.

\subsection{About soil-structure interaction.}

First of all it should be noted that interface characteristics underground structure and the surrounding soil affect considerably the seismic behavior of the corresponding system $[19,25]$. With the exception of the third one, where the soil-structure interaction effects are inherently considered in the model, methods belonging in the other two general categories can be also classified accounting or not for soil-structure interaction. For the methods where the soilstructure interaction is not considered (free field deformation methods), it is assumed that the structure will undergo the free field ground deformations, whereas for the soil-structure interaction methods, the input motion (in terms of ground displacements or equivalent forces) is modified to account of the existence of the structure.

It should be noted that pseudo-static formulations $[4,26]$ are relatively simple, and they lead to static calculation methods which can obtain the effect of underground structures under earthquake action. These formulations are widely used in engineering and specifications. Conventional free field deformation approach [18] may overestimate or underestimate structure deformations depending on the rigidity of the structure relative to the ground. It should be noted that the term "free-field deformations" describes ground strains caused by seismic waves in the absence of structures or excavations. These deformations ignore the interaction between the underground structure and the surrounding ground, but can provide a first-order estimate of the anticipated deformation of the structure. A designer may choose to impose these deformations directly on the structure. The free field deformation approach is conservative for underground 
structures stiffer than ground (and overly conservative for underground structures significantly stiffer than ground), nonconservative for underground structures more flexible than ground and can be applied for underground structures with equal stiffness to ground. On the one hand it is comparatively easy to formulate this approach and free field deformation approach was widely used with reasonable results in the past. On the other hand it provides less precision with highly variable ground conditions.

\section{STATIC FINITE ELEMENT METHOD FOR SEISMIC ANALYSIS OF UNDERGROUND STRUCTURES (SFEM)}

Application of static finite element method (SFEM) with substructure technique [27] for seismic analysis of underground structures was presented in [4]. In accordance with [4] the dynamic soil-structure interaction system can be decomposed into three sub-structures: structure, near-field and far-field soil (Figure 3) [9].

Thus we can obtain the basic soil-structure interaction equations:

$$
\left.\left\lfloor\begin{array}{ccc}
S_{s s} & S_{s n} & \\
S_{n s} & S_{n n} & S_{n b} \\
& S_{b n} & S_{b b}^{g}+S_{b b}
\end{array}\right\rfloor \mid \begin{array}{l}
\bar{u}_{s} \\
\bar{u}_{n} \\
\bar{u}_{b}
\end{array}\right\rfloor=\left\lfloor\begin{array}{c}
0 \\
0 \\
S_{b b}^{g} \bar{u}_{b}^{g}
\end{array}\right\rfloor,
$$

where $S$ is the stiffness matrix; $\bar{u}$ is the displacement vector; $s, n, b$ are subscripts, which denote structure, near-field and far-field, respectively; $g$ is superscript, which denotes excavated soil.

If we suppose that the excavated soil is a structure, we can get the following equation:

$$
\left(S_{b b}^{e}+S_{b b}^{g}\right) \bar{u}_{b}^{f}=S_{b b}^{g} \bar{u}_{b}^{g},
$$

where $e, f$ are subscripts, which denote excavated soil and free field, respectively.
Combining (1) and (2) we get:

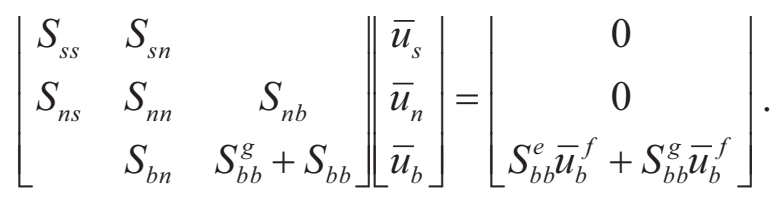

Dynamic stiffness matrix can be defined by formula:

$$
S=K+i \omega C-\omega^{2} M
$$

where $K$ is the stiffness matrix; $M$ is the mass matrix; $C$ is the damping matrix; $\omega$ is predominant circular frequency.

The ground dynamic stiffness matrix equation (4) is rewritten as (for simplicity):

$$
S_{b b}^{g}=K_{b b}^{g}+i \omega C_{b b}^{g}
$$

In order to use the free field seismic response analysis data or the soil layers seismic response analysis data to solve the underground structure seismic response two main assumptions are made. In accordance with the first assumption the accelerations of the structure and the nearfield are the same as those of the free field at the same location. In accordance with the second assumption the velocity of the structure and the near-field are the same as those of the free field at the same location [21].

The key of SFEM is that the stress state of the maximum moment of the dynamic time history analysis of the underground structure is replaced by the static state, and the computed parameters are obtained from the free field seismic response analysis. So, assumptions are to facilitate the use of the results of the free field seismic response analysis to approximate the seismic response of the underground structure. Thus the seismic response of the underground structure can be obtained by the free field seismic response [21]. 


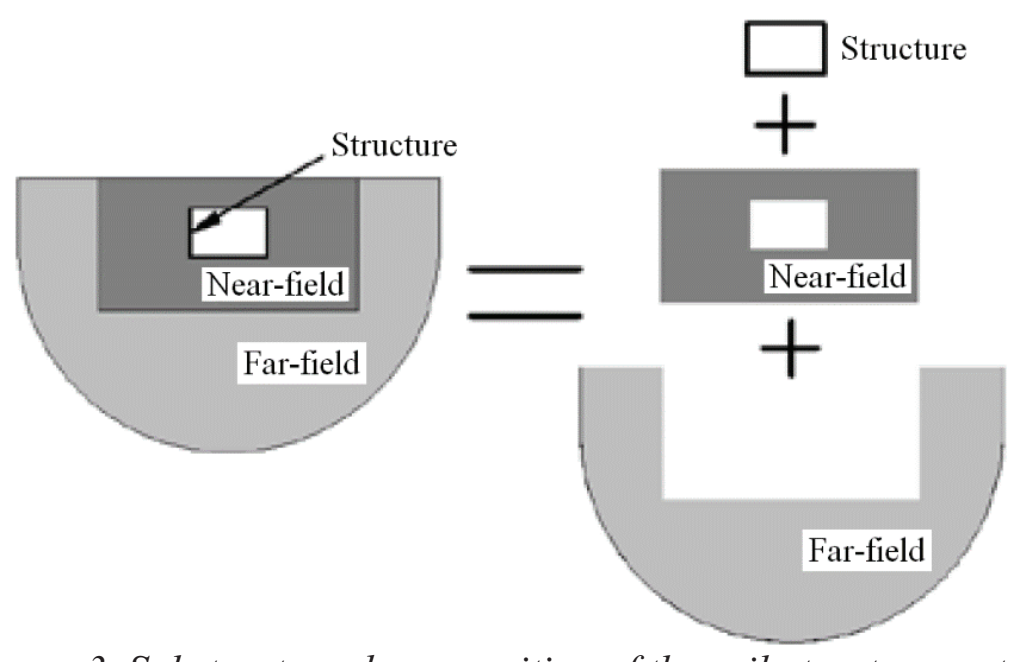

Figure 3. Substructure decomposition of the soil-structure system.

The formula (4) and (5) are brought into the formula (3), and taking into account the above two hypotheses, we can get the formula (6) as following [4]

$$
\begin{aligned}
& {\left[\begin{array}{ccc}
K_{s s} & K_{s n} & \\
K_{n s} & K_{n n} & K_{n b} \\
& K_{b n} & K_{b b}^{g}+K_{b b}
\end{array}\right]\left[\begin{array}{l}
\bar{u}_{s}^{f} \\
\bar{u}_{n}^{f} \\
\bar{u}_{b}^{f}
\end{array}\right]=} \\
& =\left[\begin{array}{ccc}
M_{s s} & M_{s n} & \\
M_{n s} & M_{n n} & M_{n b} \\
& M_{b n} & M_{b b}^{g}+M_{b b}
\end{array}\right]\left[\begin{array}{l}
\overline{\ddot{u}}_{s}^{f} \\
\overline{\ddot{u}}_{n}^{f} \\
\ddot{\ddot{u}}_{b}^{f}
\end{array}\right]- \\
& -\left[\begin{array}{ccc}
C_{s s} & C_{s n} & \\
C_{n s} & C_{n n} & C_{n b} \\
& C_{b n} & C_{b b}^{g}+C_{b b}
\end{array}\right]\left[\begin{array}{l}
\overline{\dot{u}}_{s}^{f} \\
\overline{\dot{u}}_{n}^{f} \\
\dot{\bar{u}}_{b}^{f}
\end{array}\right]+ \\
& +\left[\begin{array}{c}
0 \\
0 \\
M_{b b}^{e} \bar{u}_{f}^{f}+C_{b b}^{e} \overline{\dot{u}}_{b}^{f}+K_{b b}^{e} \bar{u}_{b}^{f}
\end{array}\right] .
\end{aligned}
$$

The left hand side of formula (6) represents the soil-structure interaction system reaction, the first term and the second term of the right of the equal sign represent internal force of the underground structure and the near-field soil (inertial force and damping force), the third term represents the boundary condition.

By the formula (6) we can get the computational model of the generalized static finite element method shown in Figure 3 [21]. It includes two parts: the internal force of the structure and the soil and the boundary conditions (boundary constraints and boundary loads).

According to the equation (6) the internal force of the structure and the soil is mainly includes the damping force and the inertia force. This part can be solved by the conventional methods [6]. However, it is necessary to improve (correct) boundary conditions [9]. Let us consider correction of boundary constraints $\left(K_{b b}^{e}\right)$.

The side and the bottom boundary are constrained by the viscoelastic boundary. Since static calculation, the boundary constraint only imposed by spring, shown in Figure 2. The value of the spring coefficient adopts the spring stiffness of the viscoelastic boundary value [4], such as the formula

$$
K_{N}=G /(2 R) ; \quad K_{T}=G / R,
$$

where $K_{N}$ is the normal spring coefficient; $K_{T}$ is the and tangential spring coefficient; $G$ is the shear modulus of the soil; $R$ is the distance between structure and boundary points.

In accordance with (6), the boundary load includes four parts: the free field displacement $\left(\bar{u}_{b}^{f}\right)$, the inertia force of the near field soil boundary ( $M_{b b}^{e} \overline{\ddot{u}}_{f}^{f}$ ), the damping force of the near field $\left(C_{b b}^{e} \overline{\dot{u}}_{b}^{\dagger}\right)$ and the equivalent load of the free field displacement $\left(K_{b b}^{e} \bar{u}_{b}^{\dagger}\right)$. 


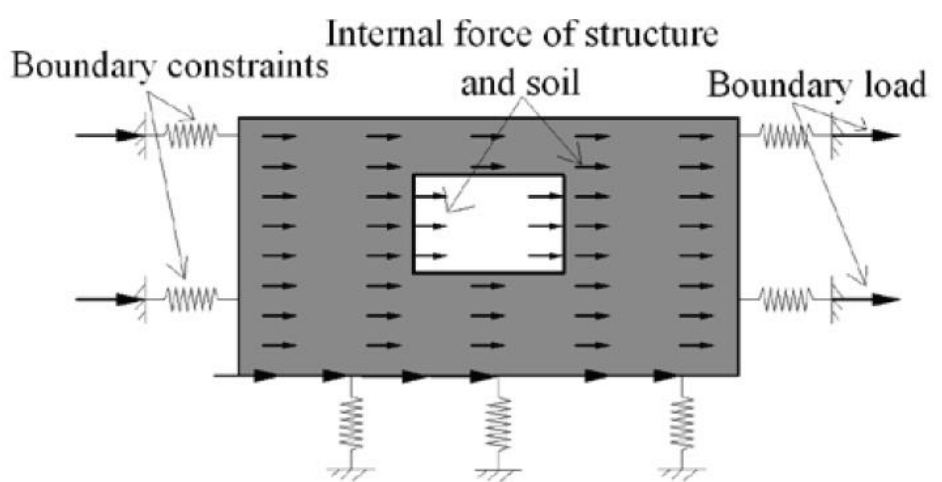

Figure 4. Generalized computational model of SFEM.

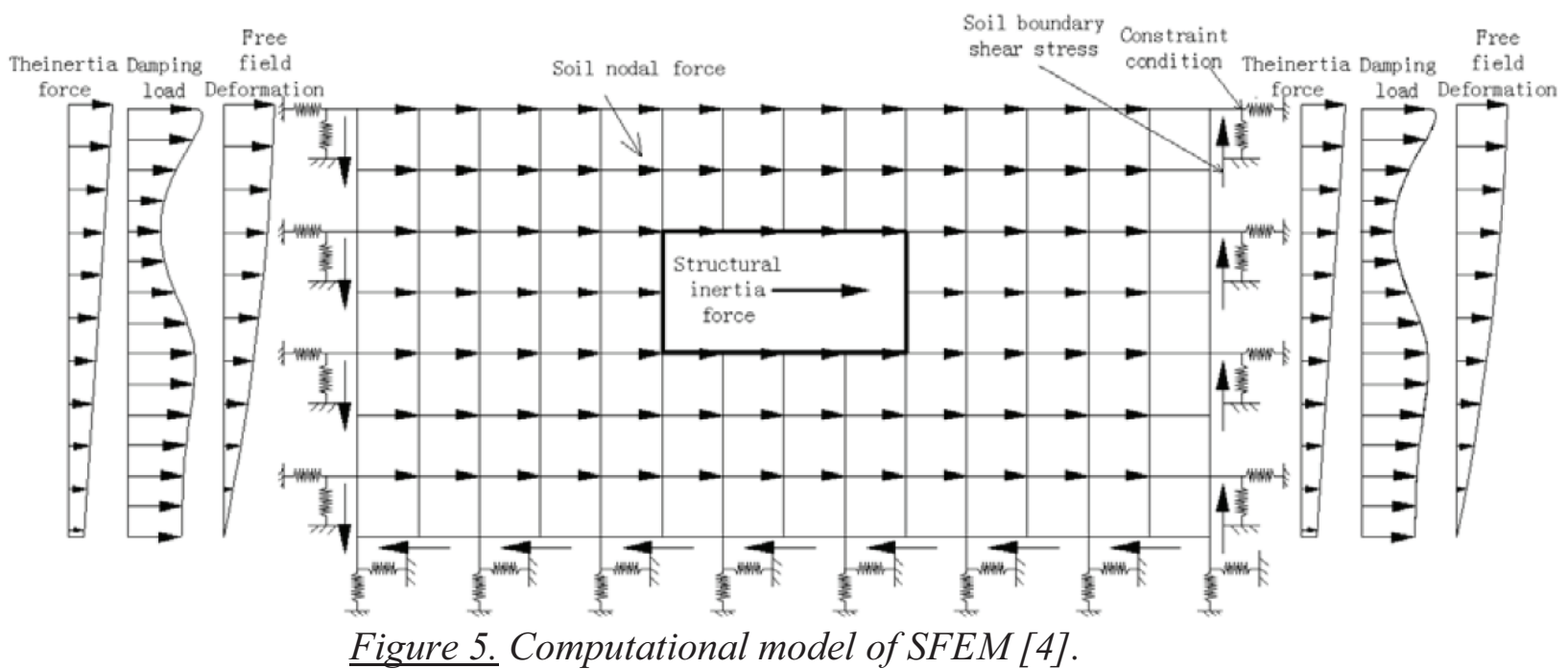

Let us consider the method of correction of corresponding boundary loads.

The free field displacement $\left(\bar{u}_{b}^{f}\right)$ can be obtained by the specialized well-known soil layers seismic response analysis software [18].

The inertia force of the near field soil boundary ( $M_{b b}^{e} \overline{\ddot{u}}_{f}^{f}$ ) can be computed with the use of the free field acceleration (can be obtained by the soil layers seismic response analysis programs) and the near field soil mass (it is also relatively easy to obtain).

The damping force of the near field $\left(C_{b b}^{e} \overline{\dot{u}}_{b}^{f}\right)$ can be computed with the use of the following formula for boundary damping force based on relationship between the Rayleigh damping and the damping coefficient

$$
\begin{aligned}
f_{c i}=c_{i} \dot{u}_{i} ; \quad c_{i}= & 2 m_{i} w_{i} \xi_{i} ; \\
& \xi_{i}=0.5 \cdot\left(\alpha_{0} / w_{i}+\alpha_{1} w_{i}\right),
\end{aligned}
$$

where $f_{c i}$ is the damping force; $c_{i}$ is the damping coefficient; $\dot{u}_{i}$ is the node speed; $m_{i}$ is the assigned node mass; $w_{i}$ is the frequency; $\xi_{i}$ is the damping ratio; $\alpha_{0}, \alpha_{1}$ are two Rayleigh damping coefficients, respectively.

The equivalent load of the free field displacement $\left(K_{b b}^{e} \bar{u}_{b}^{f}\right)$ can be equivalent to the same location soil stress of the free field, which can be obtained by the well-known soil layers seismic response analysis software.

Therefore, the computational model of SFEM is shown in Figure 5 [4].

\section{CONCLUSION}

Thus SFEM includes the three main stages. 
The first stage is solving the free field shear stress, acceleration, velocity and displacement, when the moment that the relative displacement of the soil that the underground structure located in reaches the maximum.

The second stage is computing of internal forces and parameters of boundary conditions (the spring parameters, the inertia force, the damping force, the equivalent load of the free field displacement).

The third stage is construction of the static finite element model and imposing the loads and constrains computed at the second stage as shown in Figure 4, and then making a static analysis.

Verification samples [9] show good agreement of SFEM and dynamic FEM, meaning that SFEM has good accuracy. Besides, SFEM is less affected by the size of the model, but the boundary of the model must have more than one times the width of the structure distance from the side wall.

Full dynamic time-history analysis, using threedimensional finite elements, finite difference or lumped mass models [22], is by far the most adequate method to design large and long underground structures. With this method, both the transversal and the longitudinal directions of the structure can be modeled and analyzed simultaneously, taking into account the complicated soil deposit geometry, the nonlinear behavior of the soil and the structure, using appropriate constitutive relationships, and the behavior of the soil-structure interface. While the input motion definition remains a decisive and constantly debated parameter, the main shortcoming of the method is the high computational cost, which makes its use difficult for parametric analysis, usually needed during the design phases of underground structures. To this end, full dynamic threedimensional analysis is practically used in cases of structures of significant importance (i.e. nuclear station underground ducts). Several issues, such as the appropriate simulation of the soil-tunnel interface or of the incoherence and spatial variation of the seismic input motion are still open $[28,29]$.

\section{ACKNOWLEDGEMENTS}

The Reported study was funded by Government Program of the Russian Federation "Development of science and technology" (2013-2020) within Program of Fundamental Researches of Ministry of Construction, Housing and Utilities of the Russian Federation and Russian Academy of Architecture and Construction Sciences, the Research Projects 7.1.1 and 7.1.2".

\section{REFERENCES}

1. Belostotsky A.M., Akimov P.A., Afanasyeva I.N., Kaytukov T.B. Contemporary problems of numerical modelling of unique structures and buildings. // International Journal for Computational Civil and Structural Engineering, 2017, Volume 13, Issue 2, pp. 9-34.

2. Belostotsky A.M., Akimov P.A. Nauchno-issledovatelsky tsentr StaDyO. 25 let na fronte chislennogo modelirovaniys [25th Anniversary of scientific research centre StaDyO]. // International Journal for Computational Civil and Structural Engineering, 2016, Volume 12, Issue 1, pp. 934.

3. AFPS/AFTES. Guidelines on Earthquake Design and Protection of Underground Structures. Working Group of the French Association for Seismic Engineering (AFPS) and French Tunneling Association (AFTES). Version 1, 2001.

4. Jia B., Li-ping J., Yong-qiang L. Seismic Analysis of Underground Structures Based on the Static Finite Element Method. // The Electronic Journal of Geotechnical Engineering, 2016, No. 21(06), pp. 2307-2315. 
5. Wang J.N. Seismic Design of Tunnels: A Simple State-of-the-art Design Approach. New York, Parsons Brinckerhoff Quade and Douglas Inc., 1993, 159 p.

6. Baziar M.H., Moghadam M.R., Kim D.S., Choo Y.W. Effect of underground tunnel on the ground surface acceleration. // Tunnelling and Underground Space Technology, 2014, Vol. 44, pp. 10-22.

7. Debiasi E., Gajo A., Zonta D. On the seismic response of shallow-buried rectangular structures. // Tunnelling and Underground Space Technology, 2013, Vol. 38, pp. 99-113.

8. Fabozzi S., Licata V., Autuori S., Bilotta E., Russo G., Silvestri F. Prediction of the seismic behavior of an underground railway station and a tunnel in Napoli (Ita1y). // Underground Space, 2017, Vol. 2, Issue 2, pp. 88-105.

9. Fuentes R. Internal forces of underground structures from observed displacements. // Tunnelling and Underground Space Technology, 2015, Vol. 49, pp. 50-66.

10. Kawamata Y., Nakayama M., Towhata I., Yasuda S. Dynamic behaviors of underground structures in E-Defense shaking experiments. // Soil Dynamics and Earthquake Engineering, 2016, Vol. 82, pp. 2439.

11. Romero A., Galvin P., Antonio J., Dominguez J., Tadeu A. Modelling of acoustic and elastic wave propagation from underground structures using a 2.5D BEM-FEM approach. // Engineering Analysis with Boundary Elements, 2017, Vol. 76, pp. 26-39.

12. Sandoval E., Bobet A. Effect of frequency and flexibility ratio on the seismic response of deep tunnels. // Underground Space, 2017, Vol. 2, Issue 2, pp. 125-133.

13. Wang H.-F., Lou M.-L., Chen X., Zhai Y.-M. Structure - soil - structure interaction between underground structure and ground structure. // Soil Dynamics and Earthquake Engineering, 2013, Vol. 54, pp. 31-38.
14. Wang H.-F., Lou M.-L., Zhang R.-L. Influence of presence of adjacent surface structure on seismic response of underground structure. // Soil Dynamics and Earthquake Engineering, 2017, Vol. 100, pp. 131-143.

15. Wang S. Evaluation of underground pipestructure interface for surface impact load. // Nuclear Engineering and Design, 2017, Vol. 317, pp. 59-68.

16. Wang X., Cai M. Numerical modeling of seismic wave propagation and ground motion in underground mines. // Tunnelling and Underground Space Technology, 2017, Vol. 68, pp. 211-230.

17. Zou Y., Liu H., Jing L., Cui J. A pseudo-static method for seismic responses of underground frame structures subjected to increasing excitations. // Tunnelling and Underground Space Technology, 2017, Vol. 65, pp. 106-120.

18. Hashasha Y.M.A., Hooka J.J., Schmidt B., Yaoa J.I-C. Seismic Design and Analysis of Underground Structures. // Tunnelling and Underground Space Technology, 2001, No. 16, pp. 247-293.

19. Huo H., Bodet A., Fernandez G., Ramirez J. Load Transfer Mechanisms between Underground Structure and Surrounding Ground: Evaluation of the Failure of the Daikai Station. // J. Geotech Geoenviron, 2005, No. 131(12), pp. 15221533.

20. Zeghal M., Elgamal A.W. Analysis of Site Liquefaction Using Earthquake Records. // J. Geotech. Eng. ASCE, 1994, No. 120(6), pp. 996-1017.

21. FHWA. Technical Manual for Design and Construction of Road Tunnels - Civil Elements. U.S. Department of Transportation. Federal Highway Administration. Publication No. FHWA-NHI-10-034, 2009. $702 \mathrm{p}$.

22. ISO 23469. Bases for Design of Structures - Seismic Actions for Designing Geotechnical Works. ISO International Standard. ISO TC 98/SC3/WG10, 2005. 
23. Calvi G.M., Sullivan T.J. A Model Code for Displacement-Based Seismic Design of Structures. Pavia, IUSS Press, 2009.

24. Priestley M.J.N. Myths and Fallacies in Earthquake Engineering - Conflict between Design and Reality. // Bull. Natl. Soc. Earthq. Eng. NZSEE, 1993, No. 26(3), pp. 329-341.

25. Sedarat H., Kozak A., Hashash Y.M.A., Shamsabadi A., Krimotat A. Contact Interface in Seismic Analysis of Circular Tunnels. // Tunn. Undergr. Space Technol, 2009, No. 24(4), pp. 482-490.

26. Tateishi A., 2005. A Study on Seismic Analysis Methods in the Cross Section of Underground Structures Using Static Finite Element Method. Structural Engineering // Earthquake Engineering, JSCE., 2005, No. 22(1), pp. 41-53.

27. Belostotsky A.M., Akimov P.A., Dmitriev D.S. O sovremennikh metodakh redutsirovaniya vichislitelnoy razmernosti zadach rascheta konstruktsiy, zdaniy i sooruzheniy $\mathrm{v}$ ramkakh metoda konechnikh elementov [About Contemporary Approaches to Reduction of Computational Dimension of Problems of Structural Analysis within Finite Element Method]. // International Journal for Computational Civil and Structural Engineering, 2017, Volume 13, Issue 3, pp. 19-33.

28. Ghergu M., Ionescum I.R. Structure Soil - Structure Coupling in Seismic Excitation and "City Effect". // Int. J. Eng. Sci., 2009, No. 47, pp. 347-354.

29. Semblat J.F., Kham M., Bard P.Y. Seismic-Wave Propagation in Alluvial Basins and Influence of Site-City Interaction. // Bull. Seismol. Soc. Am., 2008, No. 98(6), pp. 2665-2678.

\section{СПИСОК ЛИТЕРАТУРЫ}

1. Белостоцкий А.М., Акимов П.А., Афанасьева И.Н., Кайтуков Т.Б. Contemporary problems of numerical model- ling of unique structures and buildings. // International Journal for Computational Civil and Structural Engineering, 2017, Volume 13, Issue 2, pp. 9-34.

2. Белостоцкий А.М., Акимов П.А. Научно-исследовательский центр СтаДиО. 25 лет на фронте численного моделирования. // International Journal for Computational Civil and Structural Engineering, 2016, Volume 12, Issue 1, pp. 934.

3. AFPS/AFTES. Guidelines on Earthquake Design and Protection of Underground Structures. Working Group of the French Association for Seismic Engineering (AFPS) and French Tunneling Association (AFTES). Version 1, 2001.

4. Jia B., Li-ping J., Yong-qiang L. Seismic Analysis of Underground Structures Based on the Static Finite Element Method. // The Electronic Journal of Geotechnical Engineering, 2016, No. 21(06), pp. 2307-2315.

5. Wang J.N. Seismic Design of Tunnels: A Simple State-of-the-art Design Approach. New York, Parsons Brinckerhoff Quade and Douglas Inc., 1993, 159 p.

6. Baziar M.H., Moghadam M.R., Kim D.S., Choo Y.W. Effect of underground tunnel on the ground surface acceleration. // Tunnelling and Underground Space Technology, 2014, Vol. 44, pp. 10-22.

7. Debiasi E., Gajo A., Zonta D. On the seismic response of shallow-buried rectangular structures. // Tunnelling and Underground Space Technology, 2013, Vol. 38, pp. 99-113.

8. Fabozzi S., Licata V., Autuori S., Bilotta E., Russo G., Silvestri F. Prediction of the seismic behavior of an underground railway station and a tunnel in Napoli (Italy). // Underground Space, 2017, Vol. 2, Issue 2, pp. 88-105.

9. Fuentes R. Internal forces of underground structures from observed displacements. // Tunnelling and Underground Space Technology, 2015, Vol. 49, pp. 50-66. 
10. Kawamata Y., Nakayama M., Towhata I., Yasuda S. Dynamic behaviors of underground structures in E-Defense shaking experiments. // Soil Dynamics and Earthquake Engineering, 2016, Vol. 82, pp. 2439.

11. Romero A., Galvin P., Antonio J., Dominguez J., Tadeu A. Modelling of acoustic and elastic wave propagation from underground structures using a 2.5D BEM-FEM approach. // Engineering Analysis with Boundary Elements, 2017, Vol. 76, pp. 26-39.

12. Sandoval E., Bobet A. Effect of frequency and flexibility ratio on the seismic response of deep tunnels. // Underground Space, 2017, Vol. 2, Issue 2, pp. 125-133.

13. Wang H.-F., Lou M.-L., Chen X., Zhai Y.-M. Structure - soil - structure interaction between underground structure and ground structure. // Soil Dynamics and Earthquake Engineering, 2013, Vol. 54, pp. 31-38.

14. Wang H.-F., Lou M.-L., Zhang R.-L. Influence of presence of adjacent surface structure on seismic response of underground structure. // Soil Dynamics and Earthquake Engineering, 2017, Vol. 100, pp. 131-143.

15. Wang S. Evaluation of underground pipestructure interface for surface impact load. // Nuclear Engineering and Design, 2017, Vol. 317, pp. 59-68.

16. Wang X., Cai M. Numerical modeling of seismic wave propagation and ground motion in underground mines. // Tunnelling and Underground Space Technology, 2017, Vol. 68, pp. 211-230.

17. Zou Y., Liu H., Jing L., Cui J. A pseudostatic method for seismic responses of underground frame structures subjected to increasing excitations. // Tunnelling and Underground Space Technology, 2017, Vol. 65, pp. 106-120.

18. Hashasha Y.M.A., Hooka J.J., Schmidt B., Yaoa J.I-C. Seismic Design and Analysis of Underground Structures. //
Tunnelling and Underground Space Technology, 2001, No. 16, pp. 247-293.

19. Huo H., Bodet A., Fernandez G., Ramirez J. Load Transfer Mechanisms between Underground Structure and Surrounding Ground: Evaluation of the Failure of the Daikai Station. // J. Geotech Geoenviron, 2005, No. 131(12), pp. 15221533.

20. Zeghal M., Elgamal A.W. Analysis of Site Liquefaction Using Earthquake Records. // J. Geotech. Eng. ASCE, 1994, No. 120(6), pp. 996-1017.

21. FHWA. Technical Manual for Design and Construction of Road Tunnels - Civil Elements. U.S. Department of Transportation. Federal Highway Administration. Publication No. FHWA-NHI-10-034, 2009. $702 \mathrm{p}$.

22. ISO 23469. Bases for Design of Structures - Seismic Actions for Designing Geotechnical Works. ISO International Standard. ISO TC 98/SC3/WG10, 2005.

23. Calvi G.M., Sullivan T.J. A Model Code for Displacement-Based Seismic Design of Structures. Pavia, IUSS Press, 2009.

24. Priestley M.J.N. Myths and Fallacies in Earthquake Engineering - Conflict between Design and Reality. // Bull. Natl. Soc. Earthq. Eng. NZSEE, 1993, No. 26(3), pp. 329-341.

25. Sedarat H., Kozak A., Hashash Y.M.A., Shamsabadi A., Krimotat A. Contact Interface in Seismic Analysis of Circular Tunnels. // Tunn. Undergr. Space Technol, 2009, No. 24(4), pp. 482-490.

26. Tateishi A., 2005. A Study on Seismic Analysis Methods in the Cross Section of Underground Structures Using Static Finite Element Method. Structural Engineering // Earthquake Engineering, JSCE., 2005, No. 22(1), pp. 41-53.

27. Белостоцкий А.М., Акимов П.А., Дмитриев Д.С. О современных методах редуцирования вычислительной размерности задач расчета конструкций, зданий и сооружений в 
рамках метода конечных элементов. // International Journal for Computational Civil and Structural Engineering, 2017, Volume 13, Issue 3, pp. 19-33.

28. Ghergu M., Ionescum I.R. Structure Soil - Structure Coupling in Seismic Excitation and "City Effect". // Int. J. Eng. Sci., 2009, No. 47, pp. 347-354.

29. Semblat J.F., Kham M., Bard P.Y. Seismic-Wave Propagation in Alluvial Basins and Influence of Site-City Interaction. // Bull. Seismol. Soc. Am., 2008, No. 98(6), pp. 2665-2678.

Alexander M. Belostotsky, Corresponding Member of the Russian Academy of Architecture and Construction Sciences, Professor, Dr.Sc.; Director of Scientific Research Center "StaDyO"; Professor of Department of Structures, Buildings and Facilities, Russian University of Transport» (RUT - MIIT); Professor of Department of Architecture and Construction, Peoples' Friendship University; Professor of Department of Building Structures and Computational Mechanics, Peoples' Friendship University of Russia; office 810, 18, 3ya Ulitsa Yamskogo Polya, Moscow, 125040, Russia; phone +7 (499) 706-88-10;

E-mail:amb@stadyo.ru.

Pavel A. Akimov, Full Member of the Russian Academy of Architecture and Construction Sciences, $\mathrm{PhD}$, Professor; Executive Scientific Secretary of Russian Academy of Architecture and Construction Sciences; Vice-Director for Science Activities, Scientific Research Center "StaDyO"; Professor of Department of Architecture and Construction, Peoples' Friendship University of Russia; Professor of Department of Structural Mechanics, Tomsk State University of Architecture and Building; 24, Ul. Bolshaya Dmitrovka, 107031, Moscow, Russia; phone +7(495) 625-71-63; fax: +7 (495) 650-27-31; E-mail: akimov@raasn.ru,pavel.akimov@gmail.com.

Dmitry S. Dmitriev, Engineer, StaDyO Research \& Engineering Center; office 810, 18, 3-ya Ulitsa Yamskogo Polya, Moscow, 125040, Russia;

phone +7 (495) 706-88-10; e-mail: stadyo@stadyo.ru.

Белостоцкий Александр Михайлович, членкорреспондент РААСН, профессор, доктор технических наук; генеральный директор $3 \mathrm{AO}$ «Научноисследовательский центр СтаДиО»; профессор кафедры «Строительные конструкции, здания и сооружения» Российского университета транспорта (МИИТ); профессор Департамента архитектуры и строительства Российского университета дружбы народов; профессор кафедры строительных конструкций и вычислительной механики Пермского национального исследовательского политехнического университета; 125040, Россия, Москва, ул. 3-я Ямского Поля, д.18, офис 810; тел. +7 (499) 706-88-10;

E-mail:amb@stadyo.ru.

Акимов Павел Алексеевич, академик РААСН, профессор, доктор технических наук; главный ученый секретарь Российской академии архитектуры и строительных наук; заместитель генерального директора по науке ЗАО «Научно-исследовательский центр СтаДиО»; профессор Департамента архитектуры и строительства Российского университета дружбы народов; профессор кафедры строительной механики Томского государственного архитектурно-строительного университета; 107031, г. Москва, ул. Большая Дмитровка, д. 24, стр. 1; тел. +7(495) 625-71-63;

факс+7 (495) 650-27-31; Email: akimov@raasn.ru, pavel.akimov@gmail.com.

Дмитриев Дмитрий Сергеевич, ведущий инженеррасчетчик Отдела расчетных исследований, 3АО «Научно-исследовательский центр СтаДиО»; 125040, Россия, г. Москва ул. 3-я Ямского Поля, д.18, 8 этаж, офис 810, тел. +7 (495) 706-88-10,

e-mail: stadyo@stadyo.ru. 